Weronika Nowak

https://orcid.org/0000-0001-8863-4830

Instytut Historii Sztuki

Uniwersytet Jagielloński

https://doi.org/10.18778/2084-851X.09.05

\title{
Kaplice Najświętszego Sakramentu $w$ kolegiatach ulokowanych $w$ miastach rezydencjonalnych biskupów polskich. Funkcje - kształt architektoniczny - źródła inspiracji
}

Streszczenie. Artykuł poświęcony został zagadnieniu budowy i aranżacji kaplic Najświętszego Sakramentu w kolegiatach ulokowanych w biskupich miastach rezydencjonalnych: Warszawie, Łowiczu, Nysie, Pułtusku, Kielcach, Janowie Podlaskim i Wolborzu. Temat przechowywania Eucharystii w kościele w czasach nowożytnych nie był dotychczas przedmiotem dogłębnych analiz. Powszechnie przyjmuje się, że po Soborze Trydenckim tabernakulum zaczęto umieszczać na ołtarzu głównym świątyni. Należy jednak zaznaczyć, że Kościół nie wypracował w tej kwestii jednolitej, uniwersalnej formuły. Na soborze nie odniesiono się do problemu w sposób szczegółowy. Podkreślono, że Eucharystię należy przechowywać miejscu świętym, a regulacje wszelkich pozostałych kwestii pozostawiono ordynariuszom poszczególnych diecezji. Powszechne stało się umieszczanie Najświętszego Sakramentu na „wielkim” ołtarzu, jednak nadal z powodzeniem korzystano ze średniowiecznych wolnostojących sakramentariów lub ściennych nisz. Pod koniec XVI wieku w Państwie Kościelnym ukształtował się zwyczaj lokowania Eucharystii w specjalnie przystosowanej do tego kaplicy. Formuła ta została przyjęta także w Rzeczypospolitej. Od początku XVII wieku biskupi zaczęli inicjować translacje tabernakulów do odrębnych kaplic w najważniejszych świątyniach diecezji - katedrach - oraz kościołach kolegiackich ulokowanych w ich miastach rezydencjonalnych. W niniejszym artykule przedstawiono historię fundacji tych ostatnich, omówiono funkcje kaplic, ich pierwotny kształt, przemiany architektoniczne oraz wystrój.

Słowa kluczowe: kolegiaty, kaplice Najświętszego Sakramentu, sztuka sakralna XVII i XVIII wieku, fundacje biskupie 
ozwijający się od średniowiecza kult eucharystyczny w XVI wieku wyraźnie wyróżniał Kościół katolicki od protestantów. Na obradach XIII sesji Soboru Trydenckiego nie poruszono kwestii dokładnej lokalizacji Eucharystii w przestrzeni kościoła. W rozdziale szóstym dekretu o Najświętszym Sakramencie, opatrzonym tytułem De asservando sacrae eucharistiae sacramento et ad infirmos deferendo, powołano się na ustalenia poprzednich soborów - nicejskiego I oraz laterańskiego IV. Odwołując się do pierwszego z wymienionych, podkreślono konieczność utrwalenia bardzo słusznego i rozumnego, prastarego zwyczaju przechowywania Najświętszego Sakramentu w kościele w celu zanoszenia go chorym. Zgodnie z ustaleniami drugiego - nakazano umieszczenie Eucharystii w miejscu świętym ${ }^{1}$.

Zagadnienie ulokowania Najświętszego Sakramentu w przestrzeni kościoła nie było szeroko dyskutowane do XVI wieku. Z całą pewnością zgadzano się, że miejsce to ma być godne, czyste i zabezpieczone przed świętokradztwem, jednak w stosunku do dokładnego umiejscowienia tabernakulum w przestrzeni kościoła nie wypracowano powszechnie obowiązującej, jednolitej formuły ${ }^{2}$. W rozporządzeniach wydawanych w okresie nowożytnym dla poszczególnych diecezji biskupi zalecali umieszczenie Eucharystii w srebrnej, pozłacanej puszce i zwracali uwagę na konieczność nieustannego palenia wiecznej lampy przed Najświętszą Hostią ${ }^{3}$. Znaną formą przechowywania były sakraria usytuowane po stronie ewangelicznej chóru ${ }^{4}$ oraz ołtarze związane z zakładanymi przy kościołach bractwami eucharystycznymi ${ }^{5}$. Lokowanie tabernakulów w kaplicach brackich upowszechnione było szczególnie w Wenecji ${ }^{6}$ i Lombardii, na co wskazują liczne zachowane przykłady, spośród których można przywołać świątynie weneckie pw. św. Juliana7 i Mojżesza

\footnotetext{
Dokumenty Soborów Powszechnych 2004, s. 453.

2 Dokładne prześledzenie zachowanych akt polskich synodów diecezjalnych ukazuje, że w nowożytnej Rzeczypospolitej problem ten również nie był szczegółowo omawiany. Od soboru laterańskiego biskupi zwracali szczególną uwagę na zamykanie cyborium na klucz (SAWICKI 1963, s. 577) oraz nieustanne palenie światła przed Najświętszym Sakramentem (SAWICKI 1950, s. 265-275; SAWICKI 1952a, s. 109-118). Na synodach diecezji płockiej i gnieźnieńskiej przeprowadzonych pod koniec XVI i na początku XVII wieku odniesiono się do rozdziału De custodia eukaristie ze statutów wieluńsko-kaliskich prymasa Mikołaja Trąby z 1420 roku (FIJAŁEK/VETULANi 1875, s. 277-278; SAWICKI 1950, s. 207-227; SAWICKI 1952b, s. 266-275). Na kolejnych posiedzeniach powoływano się zwykle na ogólne ustalenia XIII sesji Soboru Trydenckiego, zob. SAWICKI 1949, s. 13-20; SAWICKI 1952b, s. 156-162, 327-330; SAWICKI 1963, s. 656.

Giberti 1542, f. 30r; PALeOtTi 1578, s. 130, 494-495; Borromeo 1599, s. 8.

4 Caspary 1954, s. 10-21; SChlegel 1960, s. 170; Borsook 1981, s. 178-181; ButTerfield/ ELAM 1999, s. 333-339.

Jako jeden z przykładów ulokowania Najświętszego Sakramentu na ołtarzu brackim można wspomnieć wenecki kościół św. Benedykta, zob. PAUL 2005, s. 378-381.

6 Matile 1997, s. 140-145.

7 Humfrey 1996, s. 372.

8 Mayer 1936, s. 282.
} 
a także okazałe kaplice brackie w Brescii - w kościele św. Jana Ewangelisty, świątyni św. św. Nazariusza i Celsusa oraz tzw. starej katedrze (il. 1)9.

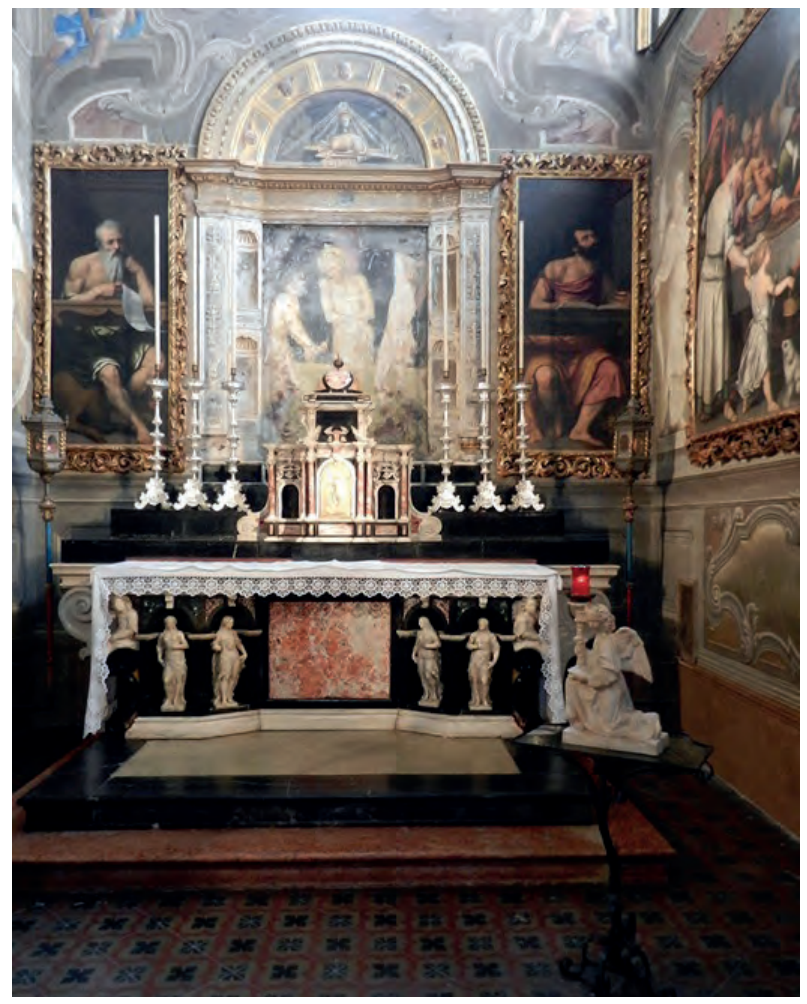

1. Stara katedra w Brescii, kaplica Najświętszego Sakramentu, lata 60. XVI wieku, fot. https://commons.wikimedia.org/wiki/ File:442BresciaRotondalnside.jpg [dostęp: 30.09.2019]

W XVI wieku w północnej i środkowej Italii Najświętszy Sakrament przechowywano na ołtarzu głównym kościoła ${ }^{10}$. Pierwsze rozporządzenie wprowadzające tę formułę w całej diecezji odnajdujemy w Konstytucjach Gibertiego opublikowanych w 1542 roku $^{11}$. Biskup Werony podkreślał przede wszystkim konieczność ustawienia tabernakulum w centrum kościoła w celu jego uwidocznienia. Eucharystia miała być bowiem pierwszym miejscem, na który pada wzrok wiernego po wejściu do świątyni ${ }^{12}$. Podobne zalecenia dotyczące przechowywania Najświętszego Sakramentu zawarto w pismach kolejnych włoskich teoretyków i ordynariuszy. Usytuowanie

\footnotetext{
9 Volta 1992, s. 34-42; SAVy 2003, s. 97-114.

10 Caglioti 2003, s. 63-70.

11 GiberTi 1542, f. 30r.

12 CASPary 1964, s. 4, 118.
} 
Eucharystii apud altare maius polecał Karol Boromeusz w Instructiones ${ }^{13}$, a także Gabriel Paleotti w Archiepiscopale Bononiense ${ }^{14}$. Zasadę tę praktykowano przede wszystkim w Lombardii, czego przykładem jest związana z rytem ambrozjańskim aranżacja przestrzeni prezbiterium katedry w Mediolanie, a także liczne jej powtórzenia, z których można jedynie wspomnieć przykłady chórów katedr w Cremonie i Vigevano. Należy jednak zaznaczyć, że chociaż wspomniana formuła lokowania tabernakulum na ołtarzu głównym była szczególnie faworyzowana, akceptowano także inne rozwiązania. Możliwość umieszczenia Najświętszego Sakramentu w innym miejscu dopuszczał również Karol Boromeusz, o czym świadczy zapis pochodzący z akt I Synodu w Mediolanie:

Episcopus diligentissime curet, ut in cathedrali, collegiatis, parochialibus et aliis quibusuis ecclesiis, ubi Sacrosancta Eucharistia custodiri solet, vel debet, in maiori altari collocetur; nisi necessaria, vel gravi de causa aliud ei videatur ${ }^{15}$.

Przechowywanie Eucharystii poza „wielkim” ołtarzem było często uwarunkowane dalszym wykorzystywaniem przeznaczonych na pomieszczenie Najświętszego Sakramentu szafek, nisz i rozbudowanych przyściennych struktur o gotyckich lub renesansowych formach. Zachowane akta wizytacyjne biskupów, a także rozporządzenia synodów diecezjalnych przekonują o funkcjonowaniu sakramentariów jeszcze długo po Soborze Trydenckim, szczególnie na terenach Europy Środkowej. Wolfgang Schneider podkreślał, że mimo iż na przeprowadzonych na początku wieku XVII synodach w Brixen, Pradze i Konstancji propagowano umieszczanie tabernakulów na ołtarzach głównych w formule more romano, dopuszczano także przechowywanie Eucharystii w szafkach, niszach i kapliczkach określanych jako more germanico ${ }^{16}$.

Dopiero w wydanym w 1614 roku przez Pawła V Rytuale Rzymskim odwołano się do kwestii ulokowania Najświętszego Sakramentu. Pomimo że polecono wówczas umiejscowienie tabernakulum na ołtarzu głównym, wyraźnie podkreślono konieczność rozdzielenia przestrzeni kultu eucharystycznego od innych funkcji sakralnych:

Hoc autem tabernaculum conopeo decenter opertum, atque ab omni alia re vacuum, in Alatri maiori, vel in alio, quod venerationi et cultui tanti Sacramenti commodius, ac decentius videatur, sit collocatum; ita ut nullum aliis sacris functionibus, aut Ecclesiasticis officiis impedimentum afferatur. Lampades coram

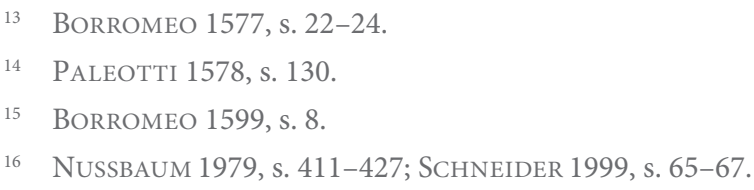


eo plures, vel saltem una, die noctuque perpetuo colluceat, curabitque Parochus, ut omnia ad ipsius Sacramenti cultum ordinata, integra, mundaque sint, et conserventur ${ }^{17}$.

Odnotowane pod koniec XVI wieku przenoszenie tabernakulów w katedrach i kolegiatach do konkretnych, naznaczonych miejsc miało zatem swoją odrębną przyczynę. Budowanie lub adaptowanie kaplic w celu pomieszczenia Najświętszego Sakramentu prowadziło do wyraźnego rozróżnienia pomiędzy chórem i sprawowanymi w nim czynnościami związanymi z funkcjonowaniem kapituły a przestrzenią przeznaczoną do kultu i prywatnej adoracji. Powstające wówczas kaplice można podzielić na dwa typy. Pierwszym, dla którego okazały wzorzec stanowiła bazylika laterańska, było przechowywanie Eucharystii w ramieniu transeptu. Drugim natomiast - upowszechniona przez budowę kaplic papieskich przy Bazylice Matki Boskiej Większej - lokalizacja Najświętszego Sakramentu w osobnej, wydzielonej przestrzeni. Przykładami adaptacji pierwszego rozwiązania były kościoły bolońskie, a także ufundowana na początku XVII wieku przez kardynała Pietra Aldobrandiniego kaplica Najświętszego Sakramentu, umieszczona na zakończeniu północnego ramienia transeptu katedry w Rawennie ${ }^{18}$. Zapoczątkowana przez Sykstusa V formuła bogato zdobionej kaplicy kopułowej, która łączyła funkcję sepulkralną z przestrzenią adoracji Najświętszego Sakramentu, przyjęła się na obszarze ówczesnego Lacjum. Jako przykłady można przywołać tu m.in. wznoszoną od lat 80. XVI wieku kaplicę z katedry w Urbino (il. 2) ${ }^{19}$, obecnie nieistniejącą, o pierwotnie zbliżonym programie ikonograficznym, kaplicę Sakramentu z katedry w Fano, ufundowaną przez biskupa Tomassa Lapisa ${ }^{20}$, oraz dekoracyjną kaplicę z katedry w Gubbio (il. 3), wzniesioną w połowie XVII wieku przez biskupa Alessandra Sperelliego ${ }^{21}$. Warto $\mathrm{w}$ tym kontekście wspomnieć także potwierdzone archiwalnie istnienie obecnie niezachowanej siedemnastowiecznej kaplicy Najświętszego Sakramentu w Fermo, którą jeszcze w latach 1712-1724 restaurował biskup Girolamo Mattei² ${ }^{22}$.

\footnotetext{
Rituale Romanum 1665, s. 85.

Sulfrini 1859, s. 25-26, 58; SCHUlz 2001, s. 733-734.

Gillgren 2011, s. 20.

20 Ugolini 2004, s. 141-144.

21 Prawdopodobnie była ona pierwotnie pomyślana jako kaplica Sakramentu oraz miejsce kultu maryjnego, co poświadcza fragment dzieła Sperelliego, w którym biskup wskazał na wyraźne połączenie pomiędzy czcią oddawaną NMP i adoracją Najświętszej Eucharystii, zob. Sperelli 1656, s. $288-289$.

22 Biskup ten miał wymienić posadzkę w kaplicy i wprowadzić dekorację sztukatorską, podobną do tych, które widział będąc w Veneto, zob. CATALANi 2012, s. 354.
} 


\section{TECHNE \\ T E X N H SERIA NOWA}

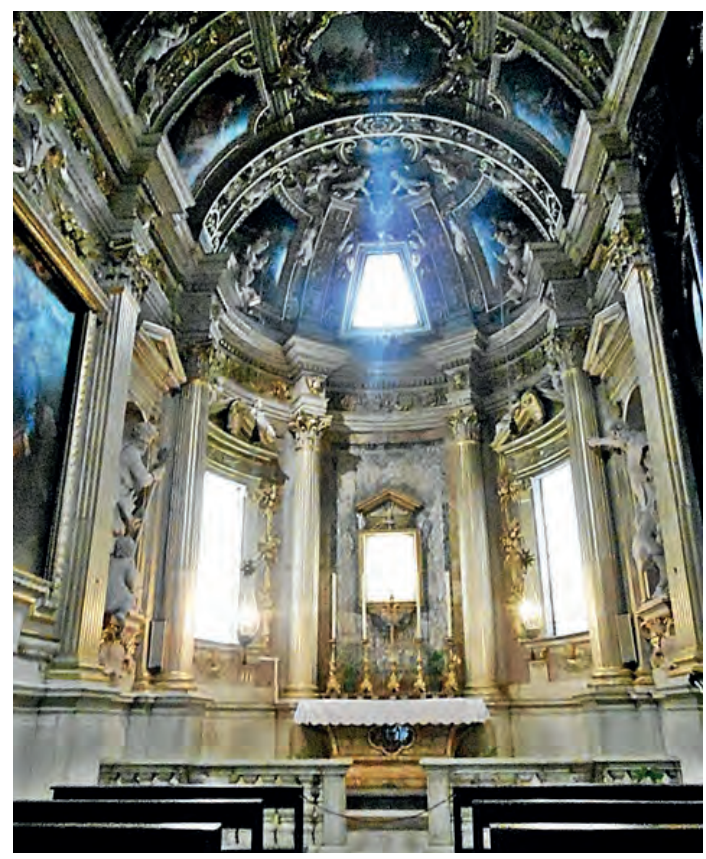

2. Katedra w Urbino, kaplica Najświętszego Sakramentu, koniec XVI wieku, dekoracja malarska autorstwa Federica Barocciego, fot. https://upload.wikimedia.org/wikipedia/ commons/b/b9/Santa_ Maria_Assunta_\%28Duomo_d\%27Urbino\%29-cappelletta_interna_2.jpg?uselang=it [dostęp: 30.09.2019]

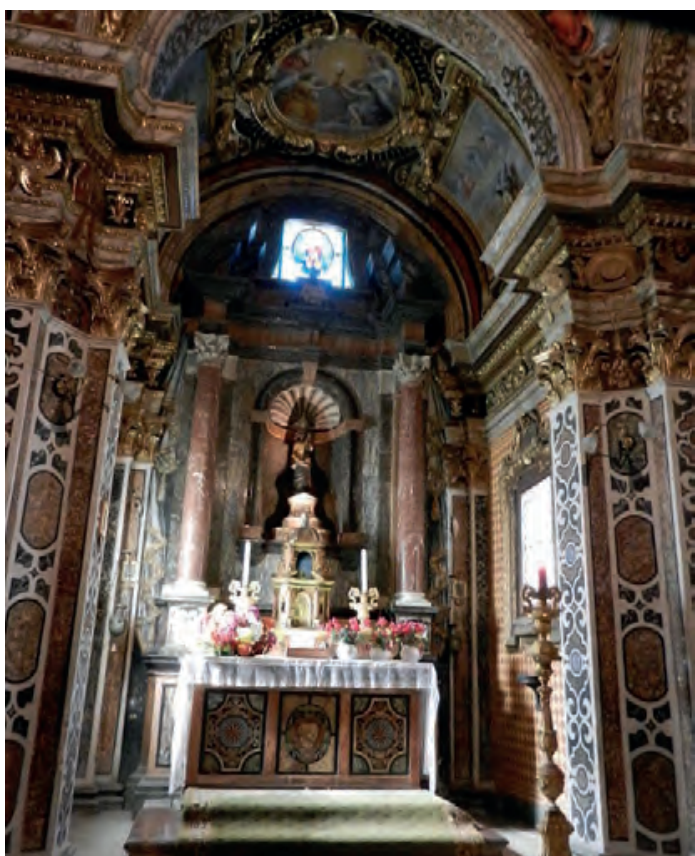

3. Katedra w Gubbio, kaplica Najświętszego Sakramentu, lata 50. XVII wieku, fundacja biskupa Alessandra Sperelliego, fot. https://commons.wikimedia.org/wiki/File:41_Gubio_ katedrala_(13).JPG?uselang=it [dostęp: 30.09.2019] 
Ukształtowany w Państwie Kościelnym zwyczaj lokowania Eucharystii w specjalnie wydzielonym miejscu został przyjęty w kościołach katedralnych i kolegiackich dawnej Rzeczypospolitej. Uwidaczniają to znane przypadki przenoszenia Najświętszego Sakramentu do osobnych kaplic, spośród których najwcześniejszy przykład stanowi przetransportowanie tabernakulum do kaplicy mansjonarskiej w katedrze krakowskiej zainicjowane w 1602 roku przez Bernarda Maciejowskiego $^{23}$. Działaniem o podobnym charakterze było - dokonane w 1619 roku z nakazu biskupa Pawła Wołuckiego - przeniesienie Eucharystii do kaplicy Górków w katedrze włocławskiej ${ }^{24}$. Translację Najświętszego Sakramentu dokładnie opisał także Wojciech Baranowski w wydanym dla katedry gnieźnieńskiej dekrecie powizytacyjnym. Prymas polecił przenieść tabernakulum z ołtarza głównego do dawnej kaplicy Sprowskiego ${ }^{25}$. Niezwykle istotny jest fakt, że rozporządzenie wydane przez arcybiskupa w 1613 roku nie miało na celu jedynie ulokowania cyborium w sąsiedztwie pochówku poprzednika, lecz chęć stworzenia zupełnie nowej przestrzeni z wykorzystaniem „uświęconych” spoliów - kamiennego domu eucharystycznego oraz żelaznej przegrody chórowej, którą nakazano przekuć na kratę do wspomnianej kaplicy ${ }^{26}$.

Właśnie tym kontekście warto rozważyć nowożytne przemiany zachodzące w kolegiatach ulokowanych w miastach rezydencjonalnych biskupów polskich. Aranżowane tam miejsca adoracji Najświętszego Sakramentu powstawały zwykle w wyniku adaptacji już istniejących kaplic. Najwcześniejszym przykładem tego typu przekształcenia była podjęta $\mathrm{w}$ latach 20 . XVII wieku gruntowna modernizacja jednej z kaplic kolegiaty warszawskiej, którą wzniesiono w połowie XV stulecia jako prywatne sacellum Wodyńskich. Z powodu braku dostatecznych przekazów źródłowych nie możemy jednak powiedzieć zbyt wiele o zakresie prowadzonych w XVII wieku prac. Wiadomo, że zwiększono wówczas głębokość kaplicy, wzniesiono kopułę, wprowadzono także nowe wyposażenie, w tym kamienny ołtarz z marmurową płaskorzeźbą ukazującą Chrystusa Ubiczowanego (il. 4) ${ }^{27}$. Omawiane przekształcenie związane było prawdopodobnie z zaadaptowaniem kaplicy do nowej funkcji. W wydanym w 1711 roku dekrecie powizytacyjnym biskup poznański, Michał Bartłomiej Tarło, wspomniał o kaplicy Najświętszego Sakramentu, która

23 CZYŻEWSKi 2007, s. 51.

24 KZSP 1988, s. 17.

25 AAG, Akta. Kap. X, f. 2. Dekret reformacyjny Gembickiego wydany został przez Stanisława Librowskiego, zob. LIBROWSKI 1980, s. 259-263.

26 Zaplanowana przez Wojciecha Baranowskiego modernizacja polegała na rozebraniu „starego”, kamiennego sakramentarium (które znajdowało się wówczas w północnej części obejścia świątyni) i aranżacji „nowej” przestrzeni kultu Najświętszego Sakramentu. W kaplicy przewidziano wprowadzenie takich zmian jak: wybicie dwóch podłużnych, zaokrąglonych u góry okien, wzniesienie ołtarza z tabernakulum oraz wykonanie dwóch klęczników: AAG, Akta. Kap. X, f. 2-3.

27 BALIŃSKI/LIPIŃSKI 1843, s. 500-503; WARDZYŃSKI 2014, s. 121; WARDZYŃSKI 2015, s. 116. 
wymagała naprawy ${ }^{28}$. Na podstawie zachowanych opisów historycznych kościoła oraz wizytacji biskupich można potwierdzić, że w drugiej połowie XVIII wieku kaplicę tę zdobił ołtarz z pozłacanym tabernakulum o formie centralnej świątyni:

Sanctissimum Eucharistia Sacramentum conservatur in separata Capella Ciborii olim Wodzińska dicta. In medio eius erecta est mensa ex latere coetu instructa tribus Magnis iuxta praescriptum Rituali super medio respositum est Tabernaculum areum auratum bene occlusum, formam Templi ad Regulas Architectonicas exterius efformati, referens, magnitudinis ad situm usumque accomodata, in quo asservantur dua Pixides cum Speciebus Smi Sacramenti Eucharistia ${ }^{29}$.

Okazały przykład wznoszenia od podstaw kaplicy Najświętszego Sakramentu stanowi fundacja arcybiskupa Jana Lipskiego w kolegiacie łowickiej. Na budowę obszernej kopułowej kaplicy otwierającej się do północnej nawy kościoła trzema arkadami biskup przekazał w 1641 roku sporą sumę 20000 złotych polskich ${ }^{30}$. Zapis ostatniej woli ordynariusza zawierał nie tylko polecenie wzniesienia kaplicy, lecz także istotne wskazówki dotyczące jej dokładnej lokalizacji. Naznaczone miejsce pochówku arcybiskupa korespondowało ze zbudowaną naprzeciwko - z fundacji poprzednika, arcybiskupa Jana Wężyka - kaplicą pw. św. Anny, którą zdobił wizerunek Ukrzyżowanego $^{31}$. Warto przypomnieć, że - zgodnie z treścią testamentu Lipskiego - motywacją prymasa było upamiętnienie nie jego osoby, lecz godności arcybiskupa gnieźnieńskiego. Faktem tym można zatem wytłumaczyć pierwotną koncepcję, która nie uwzględniała okazałego nagrobka fundatora, a jedynie płytę wpuszczoną w posadzkę przed kaplicą (il. 5) 32 . Dominantą przestrzenną miał być ołtarz z tabernakulum, usytuowany zapewne w jej centralnej części. Można przypuszczać, że wraz z powstaniem kaplicy przeniesiono do niej istniejący w kolegiacie od 1510 roku ołtarz Bożego Ciała ${ }^{33}$. Jak napisał Jacek Gajewski, na ołtarzu tym przechowywano prawdopodobnie tabernakulum z Najświętszym Sakramentem, które w 1613 roku prymas Wawrzyniec Gembicki nakazał albo na ołtarzu głównym, albo w innym

\footnotetext{
28 AAW, WG. 1, s. 181.

29 Ibidem, s. 11.

30 WiETESKA 1984, s. 1-3.

31 GAJEWSKI 1986, s. 500-503.

32 Do połowy XVIII wieku w kolegiacie łowickiej przechowywano także cynowy sarkofag prymasa, który w 1755 roku przetopiono na kandelabr, zob. LiBROWSKI 1986b, s. 347-349; GAJEWSKI 1986, s. 502.

33 LibrowsKi 1986a, s. 270. Ołtarz ten wymieniany jest w aktach kapitulnych wielokrotnie, zarówno w wieku XVI, XVII, jak i latach 70. XVIII stulecia w związku z nadawaniem przy nim altarii nowym kustoszom kapituły, zob. LiBROWSKI 1983, s. 242, 254, 330-331, 336; LibROWSKI 1986a, s. 270, 311, 313-314, 336-337, 347, 385, 400; LiBROWSKI 1986b, s. 288-289, 300, 309, 354, 605. Z zachowanych dekretów powizytacyjnych wiadomo, że przynajmniej od roku 1763 ołtarz ten znajdował się w kaplicy Lipskiego, zob. LiBROWSKi 1977, s. 131-136.
} 
$103 \mid \begin{gathered}\text { TECHNE } \\ \text { TEX N H } \\ \text { SERIA NOWA }\end{gathered}$

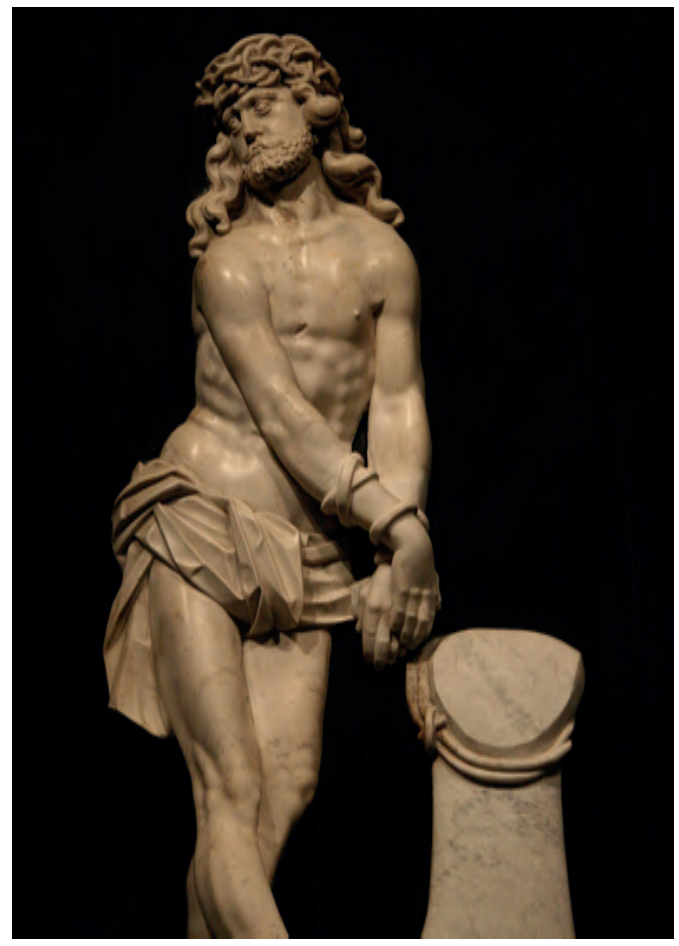

4. Kolegiata (ob. katedra) św. Jana Chrzciciela w Warszawie, marmurowa figura z ołtarza w kaplicy Najświętszego Sakramentu (Wodyńskich), pierwsza połowa XVII wieku, fot. autorka
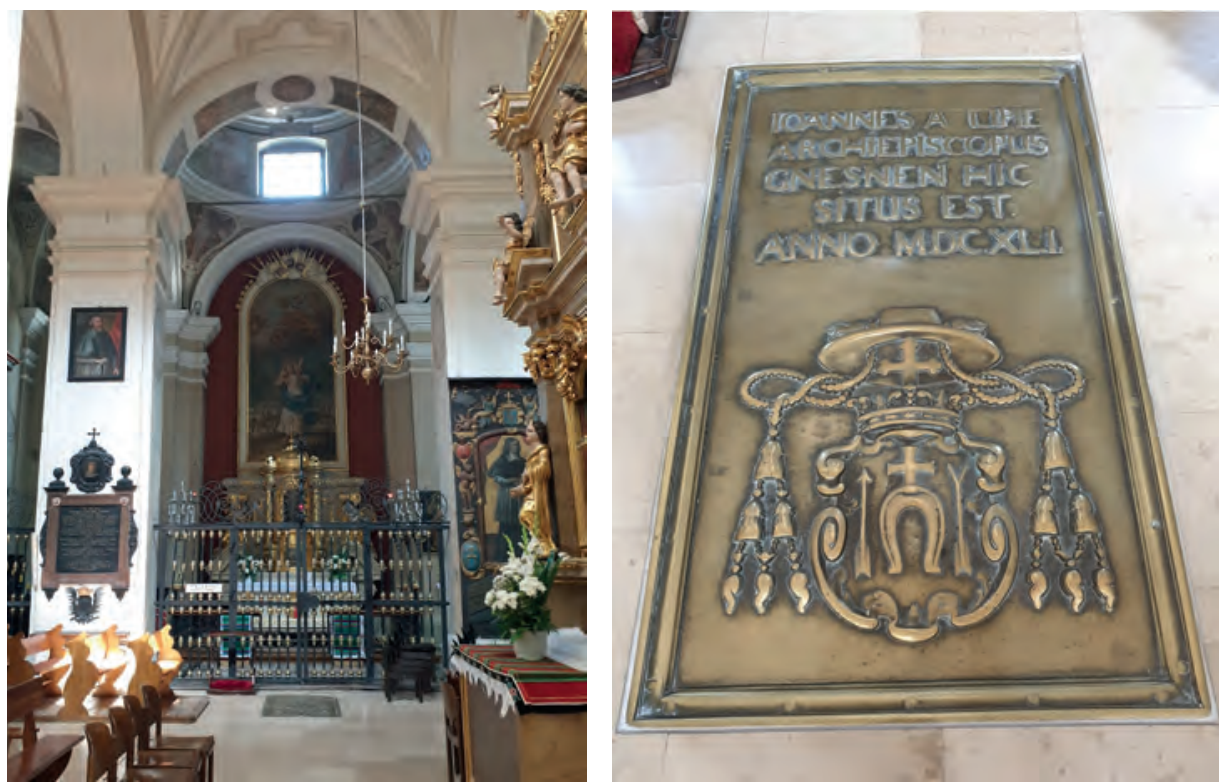

5. Kolegiata (ob. katedra) Wniebowzięcia NMP w Łowiczu, kaplica Najświętszego Sakramentu i płyta nagrobna prymasa, lata 40. XVII wieku, fundacja arcybiskupa Jana Lipskiego, obecnie przekształcona $w$ XVIII wieku, fot. autorka 
dogodnym miejscu ustawićs ${ }^{34}$. Nie wiadomo, czy polecenie arcybiskupa zostało wówczas wykonane ${ }^{35}$. Z pewnością jednak w chwili ukończenia kaplicy Lipskiego w 1647 roku dokonano translacji wyżej wspomnianego tabernakulum, być może wraz z całym ołtarzem Corporis Christi. Nową nastawę ukończono zapewne dopiero pod koniec XVII wieku, co poświadcza zachowana wzmianka źródłowa, dotycząca przetopienia nieużywanych sreber kościelnych pro foribus ciborii ad novum altare in Capella Lipsciana ${ }^{36}$. Przewidziane od początku przez Lipskiego połączenie funkcji nagrobnej z miejscem stałej adoracji Najświętszego Sakramentu, a także zaakcentowanie roli kaplicy jako przestrzeni podkreślającej godność urzędu prymasa pozwala wskazać na rzymskie konotacje. Wspominana już wcześniej, zbudowana w kościele Matki Boskiej Większej kaplica przeznaczona na pochówek Sykstusa V i jego poprzednika miała nie tylko podkreślać chwałę papieską, lecz być także miejscem kultu Najświętszej Eucharystii i przechowywanych relikwii.

Późne przykłady wznoszenia w kolegiatach kaplic Najświętszego Sakramentu związane były zwykle z istnieniem w przestrzeni kościoła sakramentariów, z których z powodzeniem korzystano jeszcze w połowie XVII wieku. Z przeprowadzonych w latach 1651-1652 oraz 1666-1667 dwóch wizytacji generalnych archidiakonatu wrocławskiego wiadomo, że w podniesionym w tym czasie do godności kolegiaty kościele św. św. Jakuba i Mikołaja w $\mathrm{Nysie}^{37}$ istniał zabezpieczony żelazną kratą kamienny dom sakramentalny, ulokowany po stronie Epistoły przy jednej z kolumn w prezbiterium świątyni. Trzymano w nim Najświętszy Sakrament umieszczony w srebrnej, pozłacanej puszce. Wzmianka $\mathrm{z}$ wizytacji przeprowadzonej $\mathrm{w}$ latach 60. wymienia także drugie, drewniane tabernakulum umieszczone in altarii maiori, które służyło wówczas już tylko do przechowywania niekonsekrowanych komunikantów ${ }^{38}$. Zarówno wspomniane sakramentarium, jak i drewniane tabernakulum, ulokowane zapewne na ołtarzu głównym kościoła, zostało zlikwidowane wraz ze wzniesieniem kaplicy Najświętszego Sakramentu, którą zbudowano z polecenia biskupa Fryderyka Heskiego w latach 1670-1680. Umieszczona po południowej stronie prezbiterium kaplica kopułowa ozdobiona została malowidłami o programie ikonograficznym charakterystycznym dla przestrzeni kultu Eucharystii - scenami Ostatniej wieczerzy i Manny z nieba na ścianach tarczowych, które dopełniono

\footnotetext{
34 ADŁ, A. Cap. Łov. IV, f. 184.

35 Zdają się jednak na to wskazywać odnotowane w aktach kapituły szeroko zakrojone prace modernizacyjne, prowadzone w kolegiacie w latach 20. i 30. XVII wieku, które pozostawały zgodne z wytycznymi zawartymi w dekrecie reformacyjnym prymasa Gembickiego. W 1625 roku ukończono naprawę posadzki w prezbiterium kościoła, a w 1635 roku rozpoczęto budowę wieży, zob. ADŁ, A. Cap. Łov. IV, f. 184-185; LibrowsKi 1983, s. 269, 301.

36 LibrowsKi 1986a, s. 337-338.

37 Przeniesienia kolegium kanoników z kościoła św. Jana Chrzciciela do świątyni św. Jakuba dokonał 10 maja 1650 roku biskup wrocławski Karol Ferdynand Waza, zob. PEDEWITZ 1905, s. 106.

38 JUNGNITZ 1902, s. 201, 639-640.
} 
wizerunkami czterech ewangelistów w pendentywach i przedstawieniem Boga Ojca w kopule kościoła. Do budowy miejsca adoracji Najświętszego Sakramentu użyto fragmentów rozebranego sakramentshaus. Można przypuszczać, że do jego struktury należały też ozdobne pilastry, które obecnie pozostają wkomponowane w południową elewację kaplicy (il. 6) ${ }^{39}$.
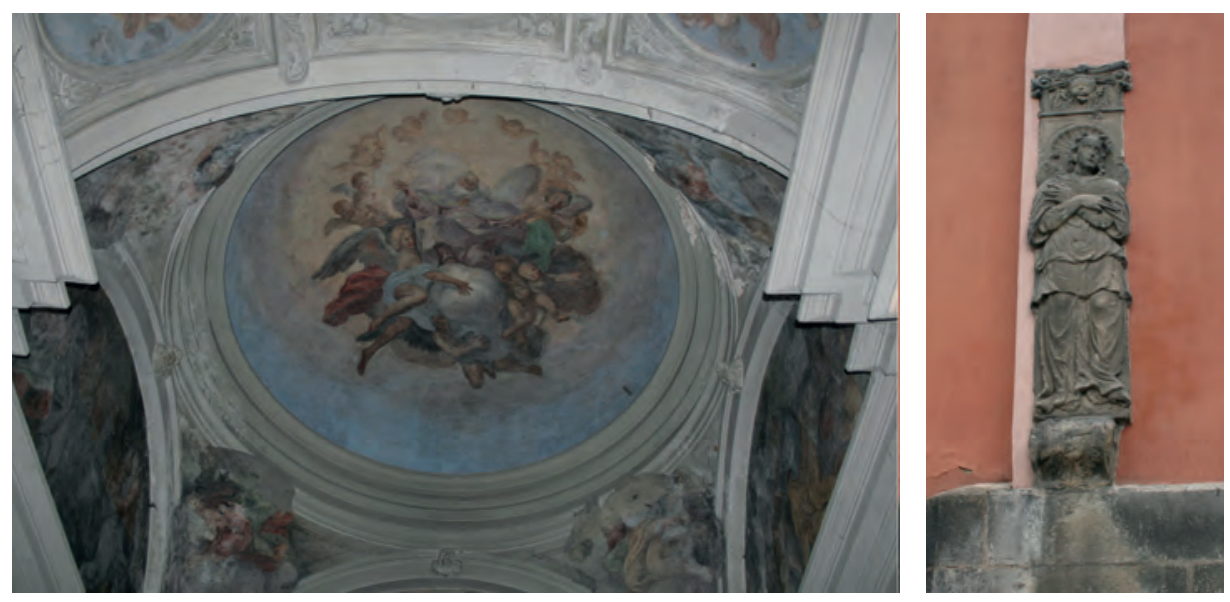

6. Kolegiata św. Jakuba w Nysie, zachowana dekoracja malarska oraz fragment elewacji kaplicy Najświętszego Sakramentu, lata 1670-1680, fundacja biskupa Fryderyka Heskiego, fot. autorka

Przykładem późnej aranżacji przestrzeni przeznaczonej na adorację Najświętszej Eucharystii są przemiany dokonane w kaplicy grobowej Andrzeja Noskowskiego w kolegiacie w Pułtusku. Wzniesioną w połowie XVI stulecia kaplicę, stanowiącą prywatne mauzoleum biskupa płockiego, obecnie uzupełnia ołtarz Najświętszego Sakramentu (il. 7) ${ }^{40}$. W aktach wizytacyjnych kościoła odnotowano, że do początku XVIII wieku w prezbiterium po stronie Ewangelii znajdował się ołtarz-cyborium, w którym przechowywano Eucharystię ${ }^{41}$. W 1714 roku ówczesny prepozyt kapituły - Adam Rostkowski ${ }^{42}$ - zobowiązał się do jego odnowienia i pozłocenia: Illsmus Dnus Praepositus offert se renovaturum et deauraturum politum Altare seu Cyborium ${ }^{43}$. W następnych latach cyborium z Najświętszym Sakramentem

39 SzewCZyk/Witkowski 2007, s. 4; SzeWCZy 2011, s. 109; HoŁownia 2008, s. 156-158.

40 WoŁosz 2011a, s. 29-32; WoŁosz 2011b, s. 53-54.

41 ADPł, A.V.1, k. 76-77; ADPł, A.V. 11, k. 71; ADPł, A. Cap. 267B, s. 131.

42 Adam Franciszek Ksawery Rostkowski (1660-1738) pełnił funkcję biskupa pomocniczego łuckiego i biskupa filadelfijskiego. Był także sędzią generalnym i kanclerzem biskupstwa płockiego przy boku Ludwika Załuskiego, zob. KozŁOWSKi 1991, s. 160-161.

43 ADPł, A. Cap. 267B, s. 894. 
prawdopodobnie przeniesiono do kaplicy grobowej biskupa Noskowskiego. Z fundacji Ludwika Bartłomieja Załuskiego wykonano nową strukturę ołtarza, a biskup płocki Antoni Sebastian Dembowski ufundował pozłotę ${ }^{44}$.

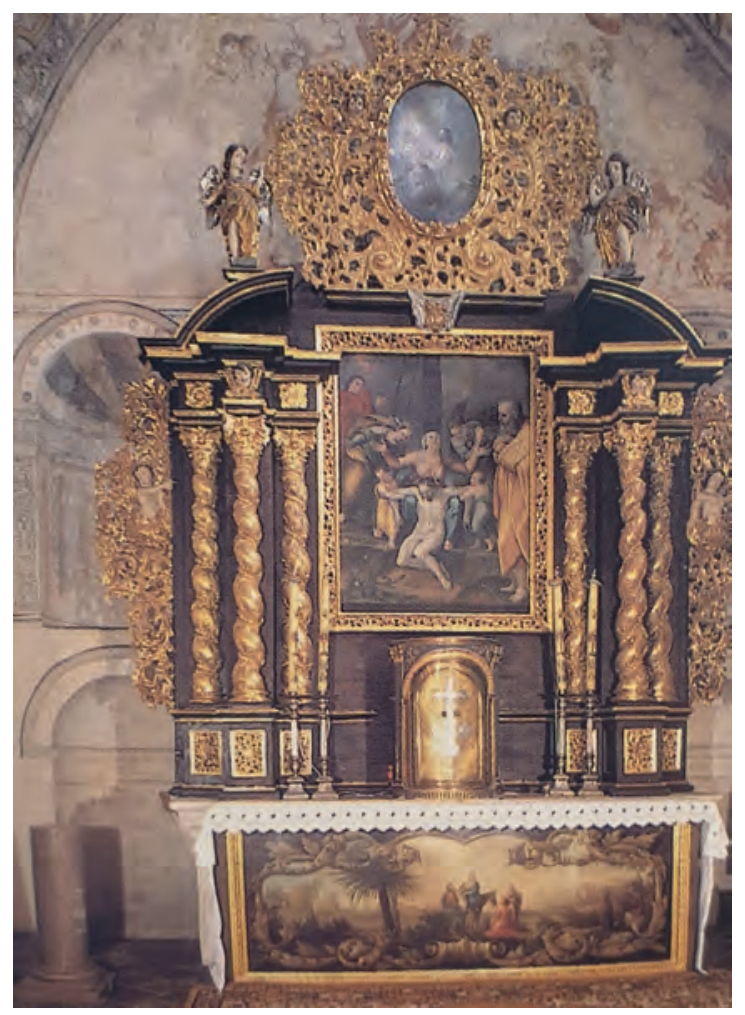

7. Kolegiata Zwiastowania NMP w Pułtusku, ołtarz Bożego Ciała w kaplicy biskupa Andrzeja Noskowskiego, pierwsza ćwierć XVIII wieku, fundacja biskupa Ludwika Załuskiego, fot. za: Bazylika pułtuska. 550 lat świątyni i Kapituły Pułtuskiej, red. Wiesław Kosek, Artur Wołosz, Pułtusk 2011, s. 62

Wolnostojące sakramentarium istniało także w kolegiacie kieleckiej. Wymieniono je w dekrecie reformacyjnym wydanym po wizytacji przeprowadzonej pod koniec XVI wieku przez kardynała Jerzego Radziwiłła ${ }^{45}$. Prawdopodobnie korzystano z niego do XVII stulecia, bowiem po 1602 roku w kościele pojawiło się nowe

\footnotetext{
44 ADPł, A.V. 275, s. 10-11, 13: Altare in Capella Noscoviana de qua Superius dictum, in mensa murata. Consecrata per Illrmum Rndmum olim Adamum Rostkowski Eppum Philadelfiensis Suffraganeum Luceoriensis, extructum per Illustrissimum et Rndmum olim Ludovicum Załuski Episcopum Plocensis; deauratum per Illustrissimum et Rndissimum Dominum Antonium Dembowski Episcopum Plocensem. Ołtarz ten został wymieniony także w aktach z wizytacji kolegiaty przez biskupa Michała Jerzego Poniatowskiego w 1775 oraz w wizytacjach dziekańskich z lat 80. XVIII wieku, zob. ADPł, A.V. 276, k. 4v-5, 32v; ADPł, A.V. dek. 304, s. 426; ADPł, A. V. dek 309, k. 140v; ADPł, A. V. dek. 313, k. 131.

45 Garbacik 1938, s. 64-67.
} 
cyborium ustawione na ołtarzu głównym ${ }^{46}$. Fundację osobnej, wydzielonej przestrzeni kultu eucharystycznego w tej świątyni możemy łączyć dopiero z biskupem krakowskim Konstantym Szaniawskim. Z polecenia ordynariusza w latach 20. XVIII wieku w nawie północnej wystawiono okazały ołtarz Ukrzyżowania. Wydzielona wokół niego przestrzeń stwarzała miejsce do prywatnej adoracji, tworząc w ten sposób quasi-kaplicę Najświętszego Sakramentu (il. 8) ${ }^{47}$. Jej ideologicznym odpowiednikiem było miejsce poświęcone kultowi cudownego obrazu Matki Boskiej Łaskawej, umieszczone analogicznie na zakończeniu południowej nawy kościoła ${ }^{48}$.

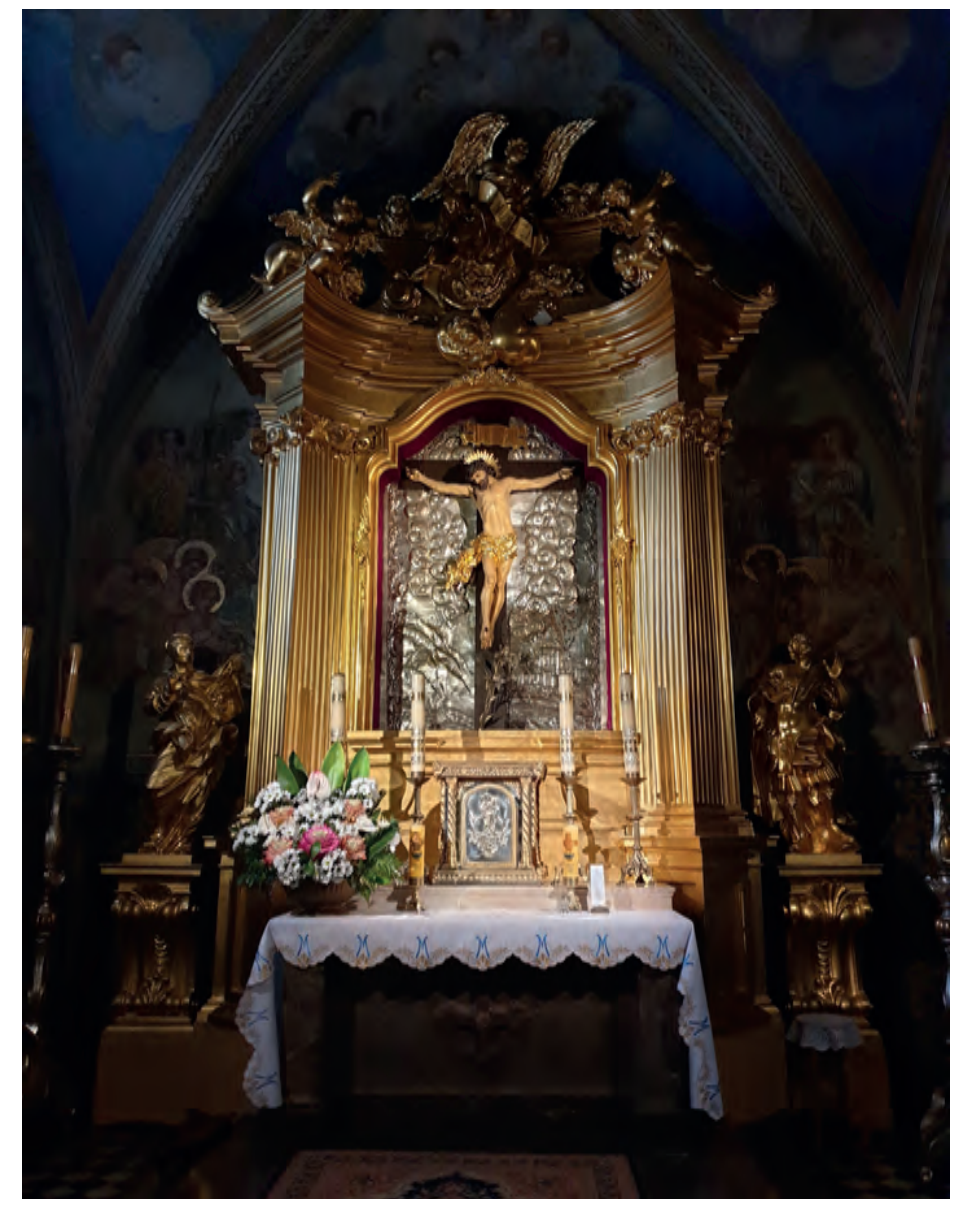

8. Kolegiata (ob. katedra) Wniebowzięcia NMP, ołtarz Ukrzyżowania w kaplicy na zakończeniu północnej nawy bocznej, lata 20. XVIII wieku, fundacja biskupa Konstantego Szaniawskiego, fot. autorka

\footnotetext{
46 ADK, PKK-38, k. 23-24.

47 Ulokowanie tabernakulum z Najświętszym Sakramentem na ołtarzu Ukrzyżowania (zwanym także ołtarzem-cyborium) potwierdza zachowany w archiwum kieleckim dokument fundacji mszy wotywnych przez oficjała krakowskiego Michała Wodzickiego, zob. ADK, PKK-16, k. 48.

48 PieniążeK-SAMEK 2000, s. 13.
} 

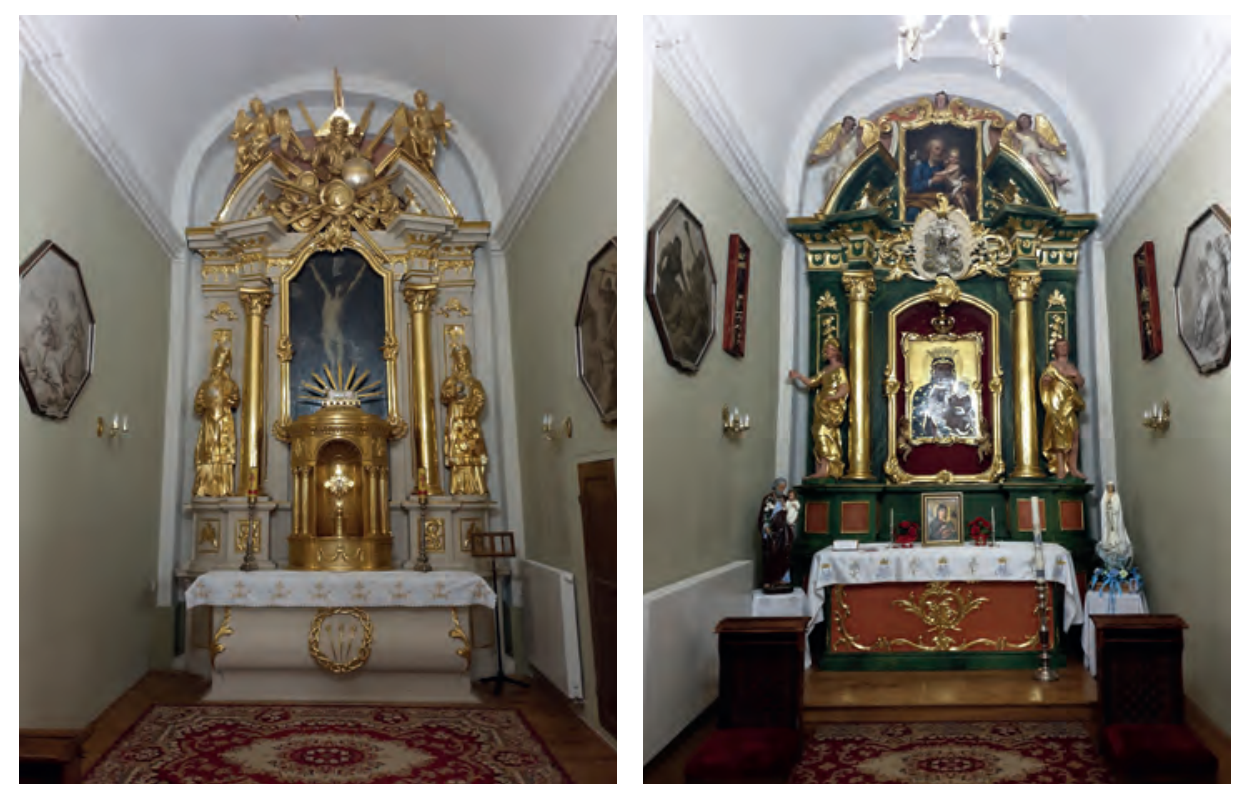

9. Kolegiata św. Trójcy w Janowie Podlaskim, ołtarze $w$ kaplicach usytuowanych na zakończeniu naw bocznych, lata 30. XVIII wieku, przekształcone $w$ XIX wieku, fot. autorka

Podobny charakter do omawianego przykładu z Kielc miała kaplica Najświętszego Sakramentu usytuowana w południowej nawie kościoła kolegiackiego pw. św. Trójcy w Janowie Podlaskim. Po północnej stronie odpowiadała jej przestrzeń mieszcząca ołtarz o wezwaniu maryjnym (il. 9) ${ }^{49}$. Obie kaplice wzniesiono w pierwszej ćwierci XVIII wieku, w trakcie gruntownej przebudowy kościoła, którą rozpoczął biskup łucki Aleksander Wyhowski. Z zachowanych archiwaliów wiadomo, że wspomniana kaplica Cyborium miała być miejscem pochówku Wyhowskiego, do czego jednak ostatecznie nie doszło, ponieważ biskup zmarł wcześnie, długo przed jej ostatecznym ukończeniem ${ }^{50}$. „Fabrykę” kościoła kontynuował jego następca - biskup Joachim Przebendowski, a ukończył Stefan Bogusław Rupniewski ${ }^{51}$. W nowo wzniesionej kaplicy postawiono odnowiony ołtarz św. Krzyża ${ }^{52}$, do którego

\footnotetext{
49 KZSP 2006, s. 82-83; Janów Podlaski 2018, s. 47-50; MirońcZuk 2018, s. 224.

50 O poleceniu tym wspomniał ksiądz Tomasz Przekaziński w spisanym w 1717 roku testamencie (ADS, D-150, s. 32): Życzyłbym sobie leżeć w tej nowej Kollegiacie w Janowie pod kaplica Ciborii, gdzie mój Dobrodziej Alexander Wyhowski miał leżeć, zaczym jeżelibym wprzód umarł, aniżeli ta kaplica dokończona była, tedy ciało per modum Depositi w kościele Farnym Janowskim grób wymurowawszy złożyć [...]. Biskup Aleksander Wyhowski został pochowany w krypcie kolegiaty św. Trójcy w Janowie Podlaskim, zob. ProkOP 2020, s. 127.

51 Mirończuk 2018, s. 50. O ukończeniu kościoła za biskupa Stefana Bogusława Rupniewskiego wspomniano w aktach wizytacji Franciszka Antoniego Kobielskiego z 1741 roku, zob. ADS, D-156, s. 322.

52 Ołtarz Ukrzyżowania, usytuowany po lewej stronie ołtarza głównego, wymieniono w opisie kościoła sporządzonym jeszcze przed jego przebudową w 1704 roku, zob. ADS, D-42, k. 491.
} 
przeniesiono tabernakulum z Najświętszym Sakramentem, przechowywane wcześniej na ołtarzu głównym ${ }^{53}$. Zgodnie z opisem sporządzonym na wizytację kościoła przez biskupa Antoniego Kobielskiego w 1741 roku ołtarz ten zdobił obraz ukazujący Ukrzyżowanie, flankowany przez rzeźbiarskie figury św. św. Piotra i Pawła, zwieńczony grupą Chrystusa Zmartwychwstałego w towarzystwie Aniołów. Na mensie ulokowano wspomniane cyborium z Najświętszą Eucharystią ${ }^{54}$.

Brak oryginalnego wyposażenia, a także niedostatek zachowanych materiałów źródłowych znacznie utrudnia omówienie kwestii ulokowania kaplicy Najświętszego Sakramentu w kolegiacie wolborskiej ${ }^{55}$. Wiadomo, że w 1633 roku Najświętszy Sakrament przechowywano jeszcze w sakramentarium umieszczonym w prezbiterium kościoła, po stronie Ewangelii. W relacji z wizyty generalnej, przeprowadzonej w 1711 roku, cyborium zostało opisane jako usytuowane w ołtarzu głównym ${ }^{56}$. O cyborium na „wielkim” ołtarzu kolegiaty wspominano jeszcze w 1754 roku $^{57}$. Po zakończonej w latach 60. XVIII wieku przebudowie świątyni tabernakulum z Najświętszą Eucharystią postawiono zapewne albo w prezbiterium, albo - tak jak w Janowie Podlaskim - w jednej z dwóch nowo wybudowanych kaplic, które umieszczono na zakończeniach naw bocznych świątyni.

Omówione kaplice Najświętszego Sakramentu powstawały zwykle z fundacji lub naznaczenia ordynariuszy diecezji. Niekiedy wznoszono je od podstaw, czego przykładem są okazałe fundacje Jana Lipskiego w Łowiczu, Ferdynanda Heskiego w Nysie i Aleksandra Wyhowskiego w Janowie Podlaskim. Zwykle adaptowano jednak przestrzeń już istniejącą, zmieniając jej funkcję przez wymianę wyposażenia. Gruntownym przemianom towarzyszyło poszanowanie tradycji miejsca. Zachowywano pochówki poprzedników, a do tworzenia wystroju kaplic wykorzystywano elementy rozbieranych struktur służących wcześniejszemu lokowaniu Eucharystii. Opracowywano programy ikonograficzne charakterystyczne dla miejsc przechowywania Najświętszego Sakramentu - historie starotestamentowe, będące prefiguracją Ofiary Chrystusa, i sceny pasyjne. Początek tworzenia omawianych kaplic możemy datować na pierwszą połowę XVII stulecia. Powstawanie miejsc adoracji Najświętszej Eucharystii w trzeciej ćwierci XVII wieku lub dopiero w wieku XVIII było związane z jedną z dwóch praktyk - przechowywaniem Sakramentu na ołtarzu głównym lub długim wykorzystywaniem przyściennych sakramentariów. Osiemnastowieczne oratoria Najświętszego Sakramentu lokowane były zwykle na zakończeniu nawy bocznej kościoła i stanowiły odpowiednik umiejscowionych po drugiej stronie

\footnotetext{
53 O pozłoconym tabernakulum wspomniano w wizytacji kościoła przeprowadzonej przez biskupa Mikołaja Prażmowskiego w 1665 roku, zob. ADS, D-149, k. 67.

54 ADS, D-156, s. 322v.

55 GRYGLEWSKI 2011, s. 81.

56 ADWł, AAG. Wiz 58, k. 2, 20.

57 ADWł, AKap. Wolb. 1, s. 7-8.
} 


\section{TECHNE \\ T E X N H \\ SERIA NOWA
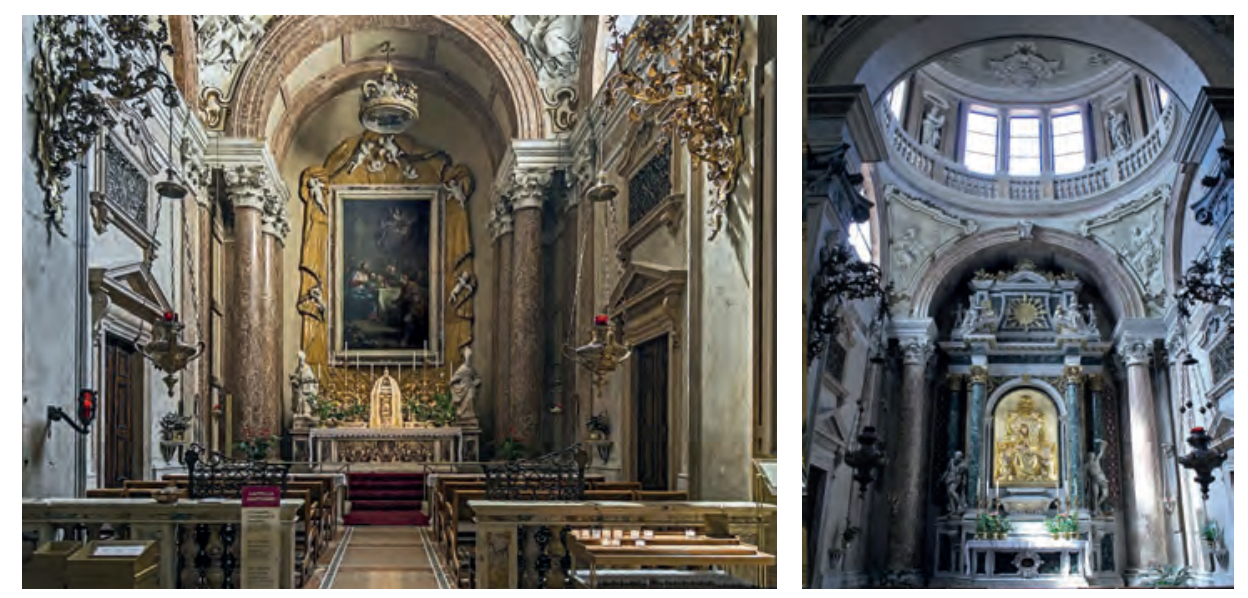

10. Katedra w Weronie, para kaplic pw. Najświętszego Sakramentu oraz Madonny Miłosiernej, lata 50.-60. XVIII wieku, fot. https://commons.wikimedia.org/wiki/File:Duomo_(Verona)_-_Interior__Nave_right_part_-_Cappella_Memo.jpg?uselang=it, https://commons. wikimedia.org/wiki/File:Cappella _della_Madonna_del_popolo,_Duomo_di_Verona.jpg?uselang=it [dostęp 30.09.2019]

kaplic maryjnych. Ten układ nawiązywać miał zapewne do znanego rzymskiego wzorca - fundacji kaplic Sykstusa V i Pawła V Borghese przy kościele Matki Boskiej Większej, a także licznych okazałych powtórzeń tego rozwiązania, spośród których można wymienić dwie kaplice zaaranżowane z polecenia kardynała Pietra Aldobrandiniego w ramionach transeptu przywoływanej już katedry raweńskiej, a także osiemnastowieczne przykłady odpowiadających sobie kaplic w Udine, Padwie ${ }^{58}$ oraz Weronie (il. 10).

\section{Bibliografia}

AAG, Akta kap. X - Archiwum Archidiecezjalne w Gnieźnie, Akta kapituły, t. X z lat 1604-1625, Decreta et ordinationes visitationis ecclesiae metropolitanae Gnesnensis totiusque cleri eiusdem ecclesiae per illmum et rmum d. Albertus Baranowski archiepiscopum Gnesnensem, legatum natum, Regni Poloniae prymatem primumque principem factae.

AAW, WG. 1 - Archiwum Archidiecezjalne w Warszawie, Wizytacje Generalne, sygn. nr 1, Antonii Onuphrii de Okęcie Okęcki Dei et Apostolicae Sedis gratia Episcopi Posnaniensis et Varsaviensis Ecclesiae insignis Collgtae Regnae Varsaviensis Visitatio 1787.

ADK, PKK-16 - Archiwum Diecezjalne w Kielcach, Akta konsystorskie kolegiaty kieleckiej, sygn. PKK-16, Akta kościoła - kolegiaty kieleckiej 1637-1837.

58 La basilica di Santa Giustina 1970, s. 456. 
ADK, PKK-38 - Archiwum Diecezjalne w Kielcach, Akta konsystorskie kolegiaty kieleckiej, sygn. PKK-38, Inventarium Apparamentorum et totius supellectilis Eccl[esi]ae collegiatae Kielcenfsisl ex mandato Ill[ustlr[issi]mi ac R[evere]ndissimi D[omi]ni Petri Gembicki Epi[scopu]s Cracovien [sis], Ducis Severiae confectum.

ADŁ, A. Cap. Łov. IV - Archiwum Diecezjalne w Łowiczu, Liber IV: Acta, constitutiones et decreta Capituli Łovicensis 1612-1623, sygn. A. 1. 4, Acta constitutiones et decreta Venerabilis Capituli Eovicensis anno Domini millesimo sescentismo duodecimo inchoata, per me Matthiam Nissenum notarium, de mandato dominorum praelatorum et canonicorum Loviciensium conscripta et in praesentem librum inducta.

ADPł, A.V. 1 - Archiwum Diecezjalne w Płocku, Acta visitationis, sygn. 1, Visitatio ecclesiae collegiatae Poltoviensis per Illum \& Rmum DD. Albertus Baranowski Episcopus Plocensis Anno domini 1592.

ADPł, A. Cap. 267B - Archiwum Diecezjalne w Płocku, Acta Capituli Pultoviensis, sygn. 267B, Acta Capitulorum Generalium et Septimanalium 1666-1717.

ADPł, A.V. 11 - Archiwum Diecezjalne w Płocku, Acta visitationis, sygn. 11, Visitatio interna Decanatus Poltoviensis Anno Domini 1609.

ADPł, A.V. 275 - Archiwum Diecezjalne w Płocku, Acta visitationis, sygn. 275, Visitatio Generalis Dembovsciana A.D. 1742.

ADPł, A.V. 276 - Archiwum Diecezjalne w Płocku, Acta visitationis, sygn. 276, Visitatio Generalis Insignis Collegiata Pultoviensis a Celsissimo Principe Michaele Georgio Poniatowski A. D. 1775.

ADPł, A.V. dek. 304 - Archiwum Diecezjalne w Płocku, Akta wizytacji dekanalnych, sygn. 304, Articuli Super quibus informatio in Generali Visitatione Diaecesis Plocensis de Statu Parochia Pultoviensis.

ADPł, A. V. dek 309 - Archiwum Diecezjalne w Płocku, Akta wizytacji dekanalnych, sygn. 309, Opisanie Parafii Pułtuskiej na Wizytę Generalną Płocka.

ADPł, A. V. dek. 313 - Archiwum Diecezjalne w Płocku, Akta wizytacji dekanalnych, sygn. 313, Articulis, super quibus informatio in Generali Visitatione Dioecesis Plocensis de Statu Parochia Pultoviensis.

ADS, D-42 - Archiwum Diecezjalne w Siedlcach, Akta Konsystorza Generalnego Janowskiego diecezji Łuckiej, sygn. D-42, Acta Actorum controversiarum institutionum, provisionum, ordinationum Illustrissimi Reverendissimi Domini Alexandri de Wyhow Wyhowski.

ADS, D-149 - Archiwum Diecezjalne w Siedlcach, Akta Konsystorza Generalnego Janowskiego diecezji Łuckiej, sygn. D-149, Acta visitationis generalis Palatinatus Podlachiae et Brestensis cum decretus reformationis ex Annus 1662-1664.

ADS, D-150 - Archiwum Diecezjalne w Siedlcach, Akta Konsystorza Generalnego Janowskiego diecezji Łuckiej, sygn. D-150, Compendium variarum Ecclesiarum Diocesis Luceoriensis et Brestensis, privilegiorum, inscriptionum, visitationum, decretorum reformationis, testamenti.

ADS, D-156 - Archiwum Diecezjalne w Siedlcach, Akta Konsystorza Generalnego Janowskiego diecezji Łuckiej, sygn. D-156, Liber hic ex fragmentis Documentorium collectorum in quo inveniuntur Erectiones Originales, et Status Ecclesiarum Parochialum Diocesis Luceoriensis et Brestensis, compositus et confectus Anno 1831.

ADWł, AAG. Wiz 58 - Archiwum Diecezjalne we Włocławku, Akta Archidiecezji Gnieźnieńskiej, sygn. AAG. Wiz 58, Acta Visitationum Generalium Ecclesiarum Volborensis, Nagorzycensis, Czarnocinensis, Chorzęcinensis, Łaznoviensis, Łodziensis, Niesulkoviensis a Galkoviensis 1 mo per R. D. Joannem Krzęcieski Archidiaconum Lanciciensis A.D. 1633, 2dno P.R. Josephum Trzciński Cancum Gnesnensis Archidiaconum Lanciciensis Annis 1715, 1717 et 1718, 3tio per P.R. Sigmundum a Przybsławice Oraczowski Custodem Livoniae Canonium.

ADWł, AKap. Wolb. 1 - Akta kapituły wolborskiej, sygn. 1, Status kościoła kolegiackiego w Wolborzu z 1753 r. 
BALIŃSKi/LipińsKi 1843 - Michał Baliński, Tymoteusz Lipiński, Starożytna Polska pod względem historycznym, jeograficznym i statystycznym opisana, t. 1, Warszawa 1843.

Borromeo 1599 - Carlo Borromeo, Acta Ecclesiae Mediolanensis, Mediolani 1599.

Borromeo 1577 - Carlo Borromeo, Instructiones fabricae et supellectilis eclesiasticae, Roma 1577.

BORSOOK 1981 - Eve Borsook, Cults and Imagery at Sant' Ambrogio in Florence, „Mitteilungen des Kunsthistorischen Institutes in Florenz", t. 25 (1981), z. 2, s. 147-202.

Butterfield/Elam 1999 - Andrew Butterfield and Caroline Elam, Desiderio da Settignano's Tabernacle of the Sacrament, „Mitteilungen des Kunsthistorischen Institutes in Florenz”, t. 43 (1999), z. 2-3, s. 333-357.

CAgLioti 2003 - Francesco Caglioti, Altari Eucaristici scolpiti del primo rinascimento qualche caso maggiore, [w:] Lo spazio e il culto. Relazioni tra edificio ecclesiale e uso liturgico dal XV al XVII secolo, red. Jörg Stabenow, Venezia 2006, s. 53-89.

CASPARY 1964 - Hans Caspary, Sakramentstabernakel in Italien bis zum Konzil von Trient. Gestalt, Ikonographie und Symoblik, kultische Funktion, München 1964.

CAtAlani 2012 - Michele Catalani, De Ecclesia Firmana. I vescovi e gli arcivescovi della Chiesa fermana. Commentario secoli III-XVIII, traduzione, introduzione e note di Emilio Tassi, Fermo 2012.

CzYŻEwSKi 2007 - Krzysztof Czyżewski, Barokizacja czy modernizacja? Przemiany katedry krakowskiej po Soborze Trydenckim, [w:] Barok i barokizacja. Materiały sesji Oddziału Krakowskiego Stowarzyszenia Historyków Sztuki, Kraków 3-4 XII 2004, red. Katarzyna Brzezina, Joanna Wolańska, Kraków 2007, s. 39-74.

Dokumenty Soborów Powszechnych 2004 - Dokumenty Soborów Powszechnych. Tekst łaciński i polski, t. 4 (1511-1870): Lateran V, Trydent, Watykan I, oprac. Arkadiusz Baron, Henryk Pietras, Kraków 2004.

FiJaŁeK/Vetulani 1875 - wyd. Jan Fijałek, Adam Vetulani, Statuty synodalne wieluńsko-kaliskie Mikołaja Trąby z r. 1420 (Starodawne Prawa Polskiego Pomniki, t. 4, Kraków 1875).

GAJEWSKI 1986 - Jacek Gajewski, Sztuka w prymasowskim Łowiczu, [w:] Łowicz. Dzieje miasta, red. Ryszard Kołodziejczyk, Warszawa 1986.

GARBACIK 1938 - Józef Garbacik, Wizytacja kolegiaty kieleckiej przez kardynała Jerzego Radziwiłła 2 września 1598, „Radostowa”, t. 3 (1938), z. 3-4, s. 64-67.

Giberti 1542 - Gian Matteo Giberti, Constitutiones, Verona 1542.

Gillgren 2011 - Peter Gillgren, Siting Federico Barocci and the Renaissance Aesthetic, Farnham 2001.

GRYGLEWsKi 2011 - Piotr Gryglewski, Dawna kolegiata w Wolborzu - fazy rozbudowy, [w:] Architektura znaczeń: studia ofiarowane prof. Zbigniewowi Bani w 65. rocznicę urodzin i 40-lecie pracy dydaktycznej, red. Anna Sylwia Czyż, Janusz Nowiński, Marta Wiraszka, Warszawa 2011, s. 76-89.

HoŁownia 2008 - Ryszard Hołownia, Pod egida kardynała Fryderyka Heskiego. Barokizacja kościoła św. Jakuba w Nysie w 4. ćw. XVII wieku, [w:] Nysa. Sztuka dawnej stolicy księstwa biskupiego, red. Ryszard Hołownia, Mateusz Kapustka, Wrocław 2008, s. 145-163.

Humfrey 1996 - Paul Humfrey, Altarpieces and altar dedications in Counter-Reformation Venice and the Veneto, „Renaissance Studies”, t. 10 (1996), s. 371-387.

Janów Podlaski 2018 - Janów Podlaski w dziejach Diecezji Siedleckiej, red. Stanisław Grabowski, Robert Mirończyk, Roman Wiszniewski, Janów Podlaski 2018.

Jungnitz 1902 - Josef Jungnitz, Visitationsberichte der Diözese Breslau. Archidiakonat Breslau, Breslau 1902.

KozŁowsKi 1991 - Jan Kozłowski, Rostkowski Adam Franciszek Ksawery herbu Dąbrowa (1660-1738), [w:] Polski słownik biograficzny, red. Emanuel Rostworowski, Henryk Markiewicz, t. 32, Wrocław 1991, s. 160-161. 
KZSP 1988 - Katalog Zabytków Sztuki w Polsce, t. 11: Dawne województwo bydgoskie, z. 18: Włocławek i okolice, red. Tadeusz Chrzanowski, Marian Kornecki, Warszawa 1988.

KZSP 2006 - Katalog Zabytków Sztuki w Polsce, t. 8: Województwo lubelskie, z. 2: Powiat Biała Podlaska, red. Katarzyna Kolendo-Korczakowa, Anna Oleńska, Marcin Zgliński, Warszawa 2006.

La basilica di Santa Giustina 1970 - La basilica di Santa Giustina: arte e storia, red. Paolo Lino Zovatto, Castelfranco Veneto 1970.

LibrowsKi 1977 - Stanisław Librowski, Sumariusz wpisów kopiariusza kapituły kolegiackiej w Łowiczu z przełomu XVIII i XIX wieku (z kontynuacja do roku 1961), „Archiwa, Biblioteki i Muzea Kościelne”, t. 34 (1977), s. 191-291.

LibROWSKI 1980 - Stanisław Librowski, Statuty kapituły metropolitalnej w Gnieźnie. Dekrety reformacyjne i ordynacje arcybiskupów z lat 1613-1810, „Archiwa, Biblioteki i Muzea Kościelne”, t. 41 (1980), s. 247-350.

LIBROWSKI 1983 - Stanisław Librowski, Statuty kapituł kolegiackich dawnej archidiecezji gnieźnieńskiej, z. 2: Statuty świetnej kapituły w Łowiczu, „Archiwa, Biblioteki i Muzea Kościelne”, t. 46 (1983), s. 203-369.

LiBROWSKI 1986a - Stanisław Librowski, Wypisy z akt kapituły w Łowiczu do zakrystii, skarbca, biblioteki, archiwum i kancelarii miejscowej kolegiaty i kapituly z lat 1525-1818, „Archiwa, Biblioteki i Muzea Kościelne", t. 52 (1986), s. 257-400.

LiBROWSKi 1986b - Stanisław Librowski, Wypisy z akt kapituły $w$ Łowiczu do zakrystii, skarbca, biblioteki, archiwum i kancelarii miejscowej kolegiaty i kapituly z lat 1525-1818, „Archiwa, Biblioteki i Muzea Kościelne”, t. 53 (1986), s. 275-393.

Matile 1997 - Michael Matile, Quadri laterali im sakralen Kontext. Studien und Materialien zur Historienmalerei in venezianischen Kirchen und Kapellen des Cinquecento, München 1997.

Mayer 1936 - August Mayer, Christ Washing His Disciples' Feet, by Tintoretto, „The Burlington Magazine for Connoisseurs", t. 69 (1936), s. 280-282.

MirońCZUk 2018 - Robert Mirończuk, Janów Biskupi. Miasto rezydencjonalne biskupów łuckich (1465-1796) i podlaskich (1818-1867), Kraków 2018.

Nussbaum 1979 - Otto Nussbaum, Die Aufbewahrung der Eucharistie, Bonn 1979.

PALEOtTi 1578 - Gabriele Paleotti, Archiepiscopale Bononiense sive De Bononiensis ecclesiae administratione, Bononia 1578.

Paul 2005 - Benjamin Paul, Jacopo Tintoretto and the Church of San Benedetto in Venice, „Mitteilungen des Kunsthistorischen Institutes in Florenz", t. 49 (2005), s. 377-412.

Pedewitz 1905 - Johann Felix Pedewitz, Historia Ecclesiastica Parochialis S. Jacobi Nissae, Parochum, red. Bernhard Ruffert, Neisse 1905.

Pieniążek-SAmek 2000 - Marta Pieniążek-Samek, Przemiany kolegiaty (obecnie katedry) kieleckiej w epoce baroku w świetle inwentarzy, cz. 2: Wiek XVIII, „Rocznik Muzeum Narodowego w Kielcach", t. 20 (2000), s. 11-84.

Pвокор 2020 - Krzysztof Rafał Prokop, Nekropolie biskupie w nowożytnej Rzeczypospolitej (XVI-XVIII w.), Kraków-Warszawa 2020.

Rituale Romanum 1665 - Rituale Romanum, Pauli V Pontificis Maximi iussu editum, Roma 1665.

SAVy 2003 - Barbara Maria Savy, Moretto e Romanino per la confraternita del Corpo di Cristo nel Duomo di Brescia: i cicli decorativi e un gonfalone perduto, „Prospettiva” 2003, nr 110-111, s. $97-121$.

SAWICKI 1949 - Jakub Sawicki, Concilia Poloniae. Źródła i studia krytyczne, t. 3: Synody diecezji łuckiej i ich statuty, Warszawa 1949.

SAWICKI 1950 - Jakub Sawicki, Concilia Poloniae. Źródła i studia krytyczne, t. 5: Synody archidiecezji gnieźnieńskiej i ich statuty, Warszawa 1950. 
SAWICKI 1952a - Jakub Sawicki, Concilia Poloniae. Źródła i studia krytyczne, t. 7: Synody diecezji poznańskiej $i$ ich statuty, Poznań 1952 (Studia nad Historią Prawa Polskiego, red. Zygmunt Wojciechowski).

SAWICKI 1952b - Jakub Sawicki, Concilia Poloniae. Źródła i studia krytyczne, t. 6: Synody diecezji płockiej i ich statuty, Warszawa 1952.

SaWicki 1963 - Jakub Sawicki, Concilia Poloniae. Źródła i studia krytyczne, t. 10: Synody diecezji wrockawskiej $i$ ich statuty, Warszawa 1963.

SCHLEgel 1960 - Ursula Schlegel, Ein Sakramentstabernakel der Frührenaissance in S. Ambrogio in Florenz, „Zeitschrift für Kunstgeschichte”, t. 23 (1960), z. 2, s. 167-173.

SCHNEIDER 1999 - Wolfgang Schneider, Aspectus Populi. Kirchenräume der katolischen Reform und ihre Bildordnungen im Bistum Würzburg, Regensburg 1999.

Schulz 2001 - Anne M. Schulz, A Tabernacle of the Sacrament in Ravenna by Giambattista Bregno, „The Burlington Magazine”, t. 143 (2001), s. 733-740.

Sperelli 1656 - Alessandro Sperelli, Il Vescovo Opera Etica, Politica, Sacra, Roma 1656.

SULFRINI 1859 - Pietro Sulfrini, Cenni storici sulla miracolosa imagine della Madonna del Sudore venerata nella chiesa metropolitana di Ravenna, Ravenna 1859.

SzEwCZyк 2011 - Aleksandra Szewczyk, Mecenat artystyczny biskupów wrocławskich $w$ dobie reformacji i potrydenckiej odnowy kościoła (1520-1609), Wrocław 2011.

SzEWCZyк/WiTKOWSKi 2007 - Aleksandra Szewczyk, Jacek Witkowski, Gotycki ołtarz główny kościoła św. Jakuba w Nysie, „Quart”, t. 2 (2007), nr 1(3), s. 3-11.

Ugolini 2004 - Guido Ugolini, I dipinti della Cappella del Sacramento nel Duomo di Fano, „Accademia Raffaello - Atti e studi” 2004, nr 1, s. 141-151.

Volta 1992 - Valentino Volta, Le vicende edilizie della collegiata insigne dei Santi Nazaro e Celso, [w:] La collegiata insigne dei Santi Nazaro e Celso in Brescia, Brescia 1992.

WARDZYŃski 2014 - Michał Wardzyński, Marmo bianco statuario z Carrary oraz inne importowane gatunki marmurów włoskich $w$ małej architekturze i rzeźbie na terenie dawnej Rzeczypospolitej od XVI do końca XVIII wieku, „Porta Aurea. Rocznik Instytutu Historii Sztuki Uniwersytetu Gdańskiego", t. 13 (2014), s. 91-135.

WARDZYŃSKI 2015 - Michał Wardzyński, Marmur i alabaster w rzeźbie i małej architekturze Rzeczypospolitej. Studium historyczno-materiałoznawcze przemian tradycji artystycznych od XVI do poczatku XVIII wieku, Warszawa 2015.

WIETESKA 1984 - Józef Wieteska, Jan Lipski fundator kaplicy Najświętszego Sakramentu w Kolegiacie towickiej i budowa oltarza, Łowicz 1984.

WoŁOsz 2011a - Artur Wołosz, Dzieje budowlane i architektura Pułtuskiej Kolegiaty, [w:] Bazylika pultuska. 550 lat świątyni i Kapituły Puttuskiej, red. Wiesław Kosek, Artur Wołosz, Pułtusk 2011, s. 9-48.

WoŁosz 2011b - Mirosława Lewandowska-Wołosz, Artur Wołosz, Dzieła sztuki w Pułtuskiej Kolegiacie, [w:] Bazylika pułtuska. 550 lat świątyni i Kapituły Pułtuskiej, red. Wiesław Kosek, Artur Wołosz, Pułtusk 2011, s. 47-74. 


\section{Chapels of the Blessed Sacrament in Polish collegiate churches located in the residential cities of polish bishops Features - architectural form - sources of inspiration}

the One of the problems that arose after the Council of Trent was the issue of where the Blessed Sacrament should be kept. During the session of the Council, this issue was not discussed in detail, only emphasizing the need to place the Eucharist inside the church building. It was commonly agreed that this place was to be dignified, clean and protected against sacrilege, but there was no uniform, universal formula for the location of the tabernacle in the temple. In addition to the well-known forms such as the placing of the Blessed Sacrament on the main altar and the sacramentals that functioned even long after the Council of Trent, other solutions were also accepted in the Catholic Church, which were also allowed by Charles Borromeo, as evidenced by one of the fragments of the First Milan Synod. A kind of novelty was therefore the creation of separate chapels in cathedrals and collegiate churches intended only to place the Blessed Sacrament, which can be divided into two types. The first, for which a magnificent model was the Lateran Basilica, was the storage of the Eucharist in the transept, distinctly continued in Bologna and Ravenna, the second - the location of the Blessed Sacrament in a separate, richly decorated chapel, initiated in the Papal State (the Chapel of Sixtus V in the Church of Our Lady Major, Cathedrals of Urbino, Fano, Gubbio and Fermo). Although the separate chapels of the Blessed Sacrament, popularized in Venice, functioned somewhat earlier at parish churches and were associated with the established Eucharistic fraternities, building them in cathedral and collegiate churches served to clearly distinguish between the space of the choir and the services celebrated in it which were related to the functioning of the chapter, and private adoration of the Blessed Sacrament. This well-established example of locating the Eucharist in a separate chapel was adopted in Poland, with which we can connect known cases of the bishops' initiated translation of tabernacles into separate cathedral chapels - the cathedral in Kraków (1602), in Gniezno (1613) and in Włocławek (1618). In this context, one should also consider the chapels of the Blessed Sacrament founded by Polish bishops in residential collegiate churches located in their cities, including those adapted in chapels which originally had different functions, with distinct respect for the tradition of the place and the use of spolia (Warsaw, Nysa, Pultusk), following the pattern connecting the storage of the Eucharist with the sepulchral function (Lipski's chapel in Lowicz) and the pairs of chapels created in the $18^{\text {th }}$ century connecting the invocation of St. Cross (altars with the tabernacle) with a Marian one (Kielce, Janów Podlaski, Wolbórz).

Keywords: collegiate chapels, chapels of the Blessed Sacrament, sacred art of the $17^{\text {th }}$ and $18^{\text {th }}$ centuries, patronage of bishops 